\title{
Immunochemical Characterization of Licorice Root Proteins and Assessment of Their Effects on Proliferation of Cancer Cells
}

\author{
Girum Tefera Belachew ${ }^{1,2}$, Mir Hadi Seyedzadeh ${ }^{2}$, Masoud Javanmardi ${ }^{3}$, Kobra Mokhtarian ${ }^{4}$, \\ Reza Falak ${ }^{5}$, Zahra Pourpak ${ }^{2}$, Mohammad Ali Mazlomi ${ }^{1}$ and Gholam Ali Kardar ${ }^{1,2 *}$ \\ ${ }^{1}$ Department of Medical Biotechnology, School of Advanced Technologies in Medicine, Tehran University of Medical Sciences, Tehran, \\ Iran \\ ${ }^{2}$ Immunology, Asthma \& Allergy Research Institute, Tehran University of Medical Sciences, Tehran, Iran \\ ${ }^{3}$ Department of Medical Biotechnology, Science and Research Branch, Islamic Azad University, Tehran, Iran \\ ${ }^{4}$ Clinical Biochemistry Research Center, Basic Health Sciences Institute, Shahrekord University of Medical Sciences, Shahrekord, Iran \\ ${ }^{5}$ Immunology Research Center, Institute of Immunology and Infectious Diseases, Iran University of Medical Sciences, Tehran, Iran \\ *Corresponding author: Gholam Ali Kardar, Department of Medical Biotechnology, School of Advanced Technologies in Medicine, \\ Immunology, Asthma \& Allergy Research Institute, Tehran University of Medical Sciences, Tehran, Iran
}

\begin{abstract}
ARTICLE INFO
Received: 蔧 April 10, 2019

Published: 幽 April 18, 2019

Citation: Girum Tefera B, Mir Hadi S, Masoud J, Kobra M, Gholam Ali K, et al. Immunochemical Characterization of Licorice Root Proteins and Assessment of Their Effects on Proliferation of Cancer Cells. Biomed J Sci \& Tech Res 17(2)-2019. BJSTR. MS.ID.002964.
\end{abstract}

Keywords: Apoptosis; Cancer cell lines; Licorice; Identification

\section{ABSTRACT}

\section{Background}

Root of licorice (Glycyrrhiza glabra) is traditionally applied in herbal medicine. In this study, we aimed to fractionate licorice root proteins and investigate their inhibitory effects on proliferation and development of gastrointestinal cancer cells.

\section{Methods}

Licorice root powder was solubilized in potassium phosphate buffer and the electrochemically resolved proteins were characterized by mass spectrometry. The antiproliferative activity of the fractionated proteins was determined by MTT assay. Moreover, we determined their capacity for induction of programmed cell death in cancer cells and peripheral blood mononuclear cells by flow cytometry.

\section{Results}

Three proteins including beta-amylase-like isoform X1 (67kDa), chitinase A (30kDa), and dirigent protein 21 -like $(20 \mathrm{kDa})$ were characterized by mass spectrometry. We found that $2 \mu \mathrm{g} / \mathrm{ml}$ concentration of $20 \mathrm{kDa}$ and $67 \mathrm{kDa}$ proteins only showed anti-proliferative effects on cancerous cells $(\mathrm{P}<0.05)$, but none of them influenced normal cells. Meanwhile, at similar concentrations the purified $30 \mathrm{kDa}$ protein inhibited proliferation of both cancerous and normal cells.

\section{Conclusion}

In this study, three major proteins of licorice root were characterized. Our findings suggest that a couple of these fractions can hinder the growth of cancer cell lines without showing any adverse effects on normal cells. Obviously, the recombinant protein technology may help us to determine the molecular mechanisms and functionality of these proteins.

\section{Introduction}

Cancer is a serious pathological state and is regarded as the first line causative mechanism of death in developed nations and also as the second primary agent of mortality in developing countries
$[1,2]$. Epidemiological studies show that increasing the life expectancy in patients with end stage cancers is almost impossible at the present time, even though, great promotion was achieved in 
treatment regimens [3]. On the other hand, Ethno medicinal herbs, such as Licorice (Glycyrrhiza glabra), as low-cost plant medicinal therapeutics could be used to prevent or aid in healing of low-grade cancers. Licorice can even be regarded as an operative botanical dietary for chemoprevention. An improving number of evidences confirm that licorice exhibits anti-carcinogenic properties. The root of licorice has been one of promising medicinal plants and were globally applied as natural medication, thus could be pointed out as 'The grandfather of herbs' [3]. It grows naturally in China, Japan, Russia, Iran, Spain, and India [4]. It was shown that Licochalcone A isolated from licorice showed in vitro inhibitory activity in HeLa cells [5], and induced apoptosis in human cervical cancer cells [6] and can prevent skin tumor initiation in mice [7].

One of the active components of Licorice, 18 $\beta$-Glycyrrhetinic acid, suppresses cell proliferation through inhibiting thromboxane synthase in non-small cell lung cancer [8]. Furthermore, oral administration of $1.0 \%$ aqueous solution of licorice to female $\mathrm{A} / \mathrm{J}$ mice in drinking water caused significant inhibition of tumor incidence [9]. The medicinal outcome of licorice, involving antiinflammatory, antiviral, and hepato-protective results, was demonstrated previously. Recently anti-cancer features of several chemical components of licorice, with proteinous or flavonoids structures were approved both in vitro and in vivo [10-12]. Evaluation of the apoptotic effects of licorice extract and its derivatives on a number of cancer cells were encouraging [13]. Studies on rats showed that some components of licorice could reverse PI3K, MMK4, MMK7, JNK1, mTOR, and Cdk2 functionalities by minimizing carcinogenesis [14]. Recently, it was shown that some protein fractions and total extract of licorice root can significantly prevent the proliferation of a couple of colon cancer cell lines (HT 29 and CT 26) and induce apoptosis [10]. Hemo-preventive approach using non-toxic botanicals is a novel therapeutic strategy for cancer management which may reduce morbidity and mortality of the patients or at least increase their life quality. In this study, we investigated the growth inhibitory effects of the protein fractions of licorice root extract on cancer cell lines.

\section{Materials and Methods}

\section{Materials}

Powder of Licorice root extract was prepared as previously described (REF). The reagents and chemicals were purchased from Sigma-Aldrich, Orange, Invitrogen, or Nunc companies. Buffers used for fast protein liquid chromatography analysis were of analytical grade. Gastrointestinal cancer cell lines including AGS, KYSE-30, and HCT-116, were purchased from National Cell Bank of Iran (Pasture Institute, Tehran, Iran) and aseptically propagated in RPMI 1640 medium (Invitrogen, USA), supplemented with 10\% fetal bovine serum (Invitrogen, USA), 1X penicillin/streptomycin (Invitrogen, USA), and then the culture flasks were kept in a humidified $\mathrm{CO}_{2}$ incubator in standard conditions.

\section{Extract Preparation}

To prepare a standard protein extract, $1 \mathrm{~g}$ of the fine powder of licorice root extract was mixed in phosphate buffered saline (PBS) pH 7.0 and stirred for $48 \mathrm{~h}$ at $4^{\circ} \mathrm{C}$, on an orbital shaker at 800 rpm [10]. Then the homogenate was clarified by centrifugation at
$13000 \mathrm{x} g$ for 10 minutes and the clear supernatant was collected as raw extract. The pigments were removed by dialysis against PBS, overnight and the protein concentration of the extract was determined by Bradford method.

\section{Protein Fractionation by FPLC}

Licorice protein extract was fractionated by ion exchange chromatography using fast protein liquid chromatography (FPLC) system. In briefly, GE Healthcare Biosciences, AKTA Prim Plus FPLC system equipped with a CL-6B DEAE-Sepharose 6B column (Sigma Aldrich, USA) was used for fractionation of the extract. First of all, the column washed and equilibrated with starting buffer (20mM Tris-HCl pH 8.0), then the dialyzed extract loaded onto the column following filtration through a $0.45 \mu \mathrm{m}$ filter. When the optical density of the elutes in $280 \mathrm{~nm}$ reached to the baseline, an increasing gradient of $\mathrm{NaCl}$ (prepared in the starting buffer) was added and the flow rate was adjusted to $1 \mathrm{ml} / \mathrm{min}$ and typical peaks were isolated. The purity and protein contents of the peaks were checked by sodium dodecyl sulphate polyacrylamide gel electrophoresis (SDS-PAGE).

\section{SDS-PAGE and Electro-Elution}

Fractionated proteins were further resolved on 10\% SDS-PAGE. Following colloidal Coomassie blue staining the desired protein bands were cut and removed from the gel and after destining were subjected to mass spectrometry analysis [10].

\section{Protein Characterization by Mass Spectrometry}

Following in gel digestion, Mass spectrometry analysis was performed using an ABI 4800 MALDI TOF/TOF analyzer (Applied Biosystems, Foster City, CA, USA). Mass spectra were recorded in reflector positive mode with a scanning range of 900-4000 Da. Five monoisotopic precursors from each purified fraction with signal/noise $(\mathrm{S} / \mathrm{N})$ ratios greater than 200 were selected for mass spectrometry (MS/MS). Peptide mass fingerprinting (PMF) of the target proteins were determined by searching MASCOT database and employing Biotools software (Bruker Daltonik GMBH, Germany).

\section{Cytotoxicity Assay}

The anticancer activity of the fractionated proteins was determined by MTT dye assay (Sigma- Aldrich, Germany). The cancer cell lines and peripheral blood mononuclear cells (PBMC) were seeded in triplicate in 96 well plates with cell densities of $5 \times 10^{3}$ and $5 \times 10^{4}$ cells/well in $200 \mu$ l volume, respectively. Following an overnight incubation, cells were treated with each of protein fractions in different concentrations $(2,5$, and $10 \mu \mathrm{g} / \mathrm{ml})$. Then $20 \mu \mathrm{l}$ of MTT stock solution $(5 \mathrm{mg} / \mathrm{ml})$ was added to each well and incubated for $4 \mathrm{~h}$. Afterward, $100 \mu \mathrm{l}$ of DMSO was added to each well and the plates incubated for further 15 minutes on a shaker. Finally, the absorbance was measured at $570 \mathrm{~nm}$ using microplate reader (Bio-TEK, USA).

\section{Apoptosis Assay}

To determine cytotoxic effects of the fractions, cancer cell lines as well as PBMC were seeded with cell densities of $4 \times 10^{4}$ and $1.5 \times 10^{5}$ cells/well in 24-well culture plate in $1 \mathrm{ml}$ volumes, respectively and the cells were treated as described above and 
incubated overnight in standard conditions. For detection of apoptosis, cells were stained simultaneously with FITC-conjugated Annexin V and propidium iodide (PI; Invitrogen, USA) according to the manufacturer's instructions. Total numbers of apoptotic cells were determined by calculation of Annexin $\mathrm{V}^{+}$and $\mathrm{PI}^{-}$cells $(\mathrm{Q} 3$, as early apoptosis events) together with Annexin $\mathrm{V}^{+}$and $\mathrm{PI}^{+}(\mathrm{Q} 2$, as late apoptosis events) cells.

\section{Results}

\section{Identification and Characterization of Licorice Proteins by Mass Spectrometry}

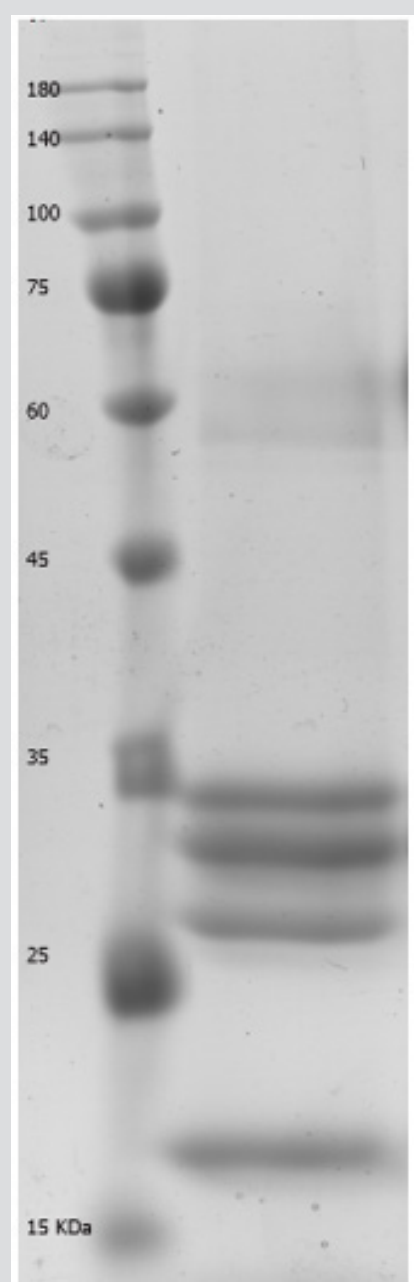

Figure 1: Separated protein fractions from licorice root extract by $12 \%$ SDS-PAGE polyacrylamide gel electrophoresis. M molecular weight marker.

Table 1: The three characterized protein fractions result from MALDI-TOF-Ms and MASCOT Search engine in the NCBInr database.

\begin{tabular}{|c|c|c|c|c|c|c|}
\hline Protein band & Protein name & Protein MW (Da)/PI & Protein Score & Accession key & Observed mass & Peptide sequence \\
\hline Fraction 1 & $\begin{array}{c}\text { Diligent protein } \\
\text { 21-like }\end{array}$ & $20378 / 5.80$ & 86 & gi|1012226336 & 1614.8990 & K. LTHLHFYYHDIR.N \\
\hline Fraction 2 & Chitinase A & $30734 / 4.61$ & 63 & gi|189095136 & 1110.5375 & K. YGGIMLWNR.Y \\
\hline Fraction 5 & $\begin{array}{c}\text { Beta amylase-like } \\
\text { isoform X1 }\end{array}$ & $67130 / 6.02$ & 238 & gi|659110762 & 2102.1089 & NKEYLTLGVDNQPLFHGR.T \\
\hline & & & & & 1641.8274 & R. HHAILNFTCLEMR.N \\
\hline
\end{tabular}


The peptide mass fingerprinting (PMF) of the SDS-PAGE resolved proteins (Figure 1) were obtained by MALDI-TOF-MS. The spectrum was emitted from in-gel trypsin digestion. The spectra of five protein fractions were searched against the NCBInr database using MASCOT. We restricted the quest to Viridiplantae (4046923 sequences) which finally yielded just three matches. In brief, beta-amylase-like isoform $\mathrm{X} 1(67 \mathrm{kDa})$, chitinase $\mathrm{A}(30 \mathrm{kDa})$, and dirigent protein 21-like (20kDa) were detected. During the protein identification and characterization procedure for our 5 protein fractions, the spectra were searched against the NCBInr database restricted to Viridiplantae (4046923 sequences) and yielded just three matches. The detected peptides matched to dirigent protein 21-like, a protein which is found in the plant is known as Arachis duranensis, beta-amylase-like isoform X1, a protein which is found in Cucumis melon plant and chitinase A which is also found in the plant called Ananas comosus, respectively (Table 1). But we did not get any significant matches from the other two fractions, (fraction 3 and 4) by MASCOT Search engine in the NCBInr database.

\section{Anti-Proliferative Effects of The Licorice Protein Fractions}

The MTT assay demonstrated that $2-5 \mu \mathrm{g} / \mathrm{ml}$ concentrations of beta amylase-like isoform X1 $(67 \mathrm{kDa})$ have a significant antiproliferative effect on AGS and KYSE-30 $(\mathrm{P}<0.05)$ cells, without any adverse effects on normal PBMC $(\mathrm{P}>0.05)$. Furthermore, $2 \mu \mathrm{g} / \mathrm{ml}$ of dirigent protein 21 -like $(20 \mathrm{kDa})$ showed a significant inhibitory effect on each of the studied cancer cell lines $(\mathrm{P}<0.05)$. While, Chitinase A $(30 \mathrm{kDa})$ showed anti-proliferative effects on both cancerous cells and normal PBMCs $(\mathrm{P}<0.05)$. Statistically, at $2 \mu \mathrm{g} / \mathrm{ml}$ the anti-proliferative effect of dirigent protein 21-like was more significant on cancerous cells than other simultaneously characterized proteins. Treatment with $2 \mu \mathrm{g} / \mathrm{ml}$ of dirigent protein 21-like proved that the viability of the cancerous cells was considerably less than control PBMC and they were more prone to apoptosis (Figure 2).

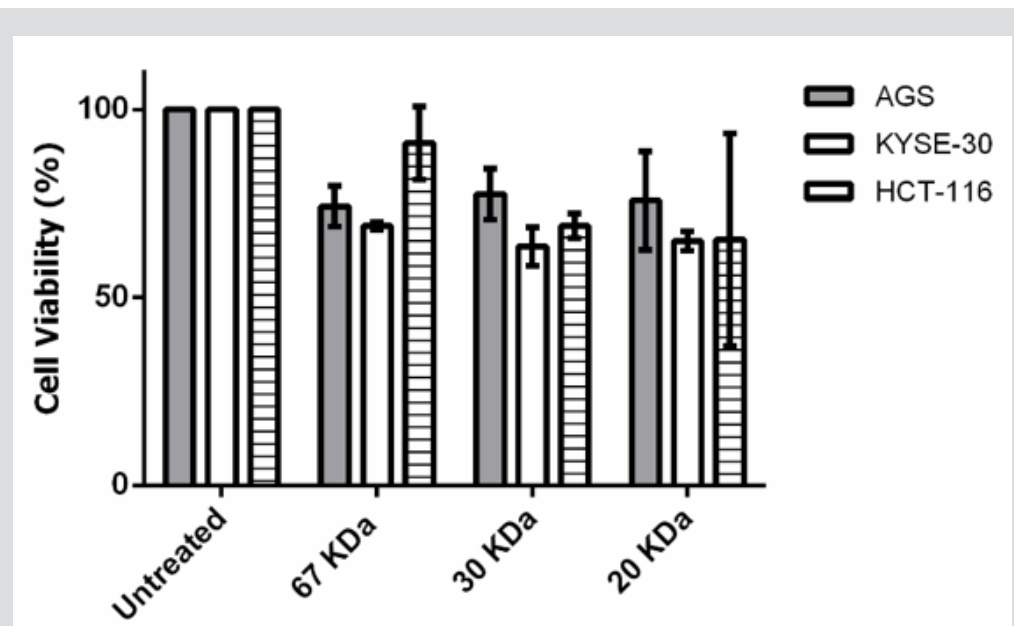

Figure 2: Effects of the three characterized protein fractions on the viability of the AGS, KYSE-30, HCT-116 cells in vitro. Cells were treated with $2 \mu \mathrm{g} / \mathrm{ml}$ for $24 \mathrm{hr}$.

\section{Licorice Proteins Induce Stimulated Apoptosis of Cancer Cells}

After proving that fraction containing 30, 20 and $67 \mathrm{kDa}$ proteins were capable to decrease the viability of cancerous cells; we checked their effect on stimulated apoptosis. To achieve this, the cells were incubated for $24 \mathrm{~h}$ with the same concentration $(2 \mu \mathrm{g} / \mathrm{ml})$ of the aforementioned protein fractions. Purified dirigent protein 21-like, beta-amylase- X1 like isoform and chitinase A were capable to induce apoptosis in the target cancer cell lines (Figure 3). Table 2 showed the comparison of the mean \pm standard deviation and p-values of the treated $(2 \mu \mathrm{g} / \mathrm{ml})$ and the untreated cancer cell lines and PBMCs in induction of apoptosis. As shown in Figure 4, very similar to the results of anti-proliferative assay, only 30 KDa protein induced apoptosis in normal PBMC cells (Figure 4).

Table 2: Comparison of the mean \pm standard deviation and p-values of the treated $(2 \mu \mathrm{g} / \mathrm{ml})$ and the untreated cancer cell lines and PBMCs in apoptosis assay.

\begin{tabular}{|c|c|c|c|c|}
\hline \multirow{2}{*}{ Groups } & \multicolumn{4}{|c|}{ Cancer Cell Lines } \\
\cline { 2 - 5 } & KYSE-30 & AGS & HCT-116 & PBMC \\
\hline Untreated & $25.57 \pm 7.07$ & $7.34 \pm 1.98$ & $9.34 \pm 1.89$ & $23.16 \pm 5.36$ \\
\hline $\begin{array}{c}\text { Beta amylase-like isoform } \\
\text { X1 }\end{array}$ & $\begin{array}{c}58.22 \pm 13.34 \\
\text { P } 0.020\end{array}$ & $\begin{array}{c}13.10 \pm 3.31 \\
\text { P } 0.061\end{array}$ & $46.52 \pm 2.89$ P 0.00 & $24.54 \pm 4.48$ P 0.750 \\
\hline Chitinase A & $\begin{array}{c}53.78 \pm 12.67 \\
\text { P 0.028 }\end{array}$ & $\begin{array}{c}18.54 \pm 4.85 \\
\text { P } 0.021\end{array}$ & $31.30 \pm 4.07$ P 0.001 & $39.80 \pm 9.34$ P 0.056 \\
\hline Diligent protein 21-like & $\begin{array}{c}46.59 \pm 11.27 \\
\text { P } 0.052\end{array}$ & $\begin{array}{c}26.29 \pm 7.62 \\
\text { P } 0.014\end{array}$ & $43.15 \pm 3.06$ P 0.00 & $22.57 \pm 0.7773$ P 0.858 \\
\hline
\end{tabular}




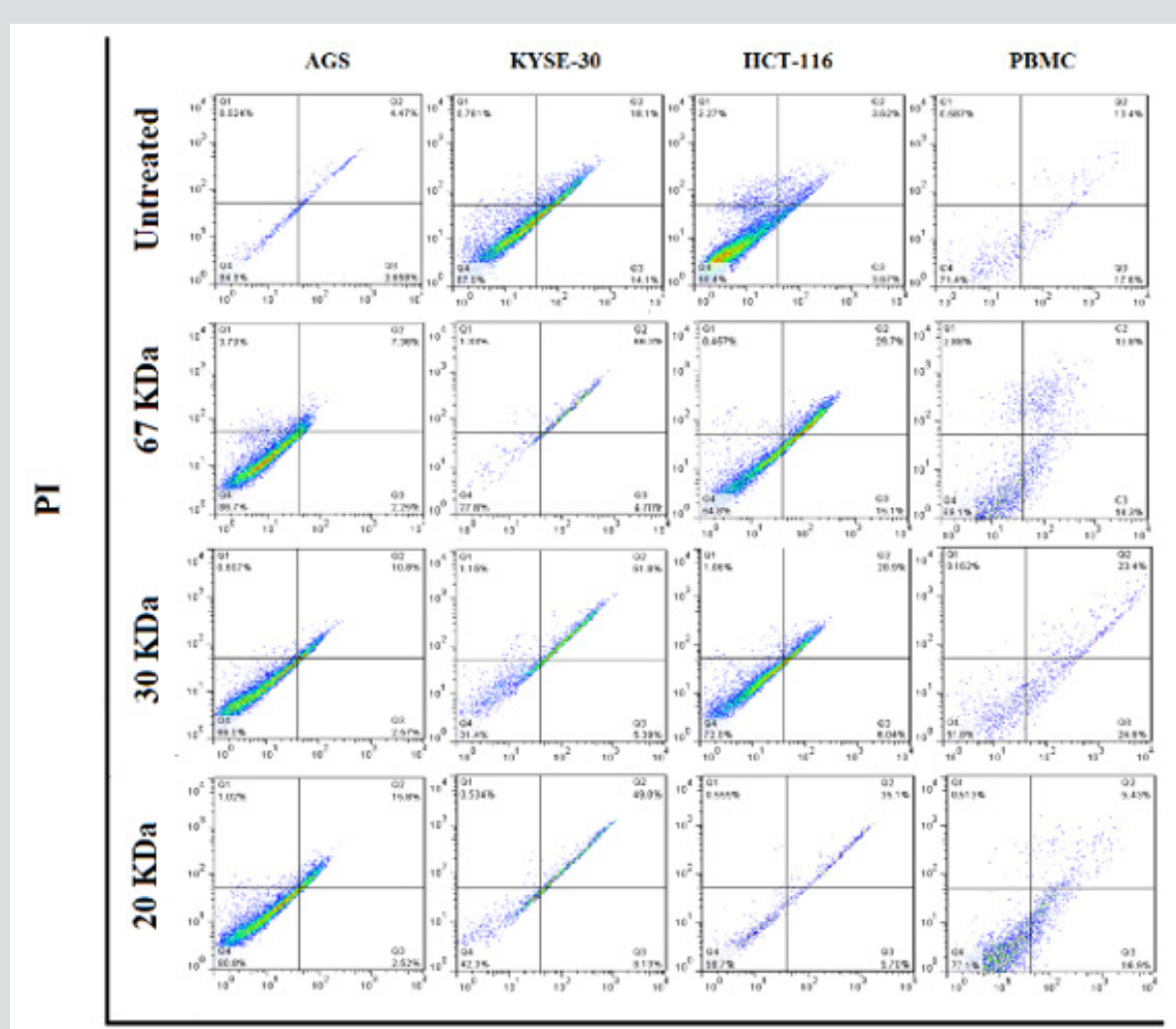

Annexin V - FITC

Figure 3: The three characterized protein fractions from licorice root extract induced apoptosis in gastro intestinal cancer cell lines. Cells were treated with $2 \mu \mathrm{g} / \mathrm{ml}$ for $24 \mathrm{hr}$.

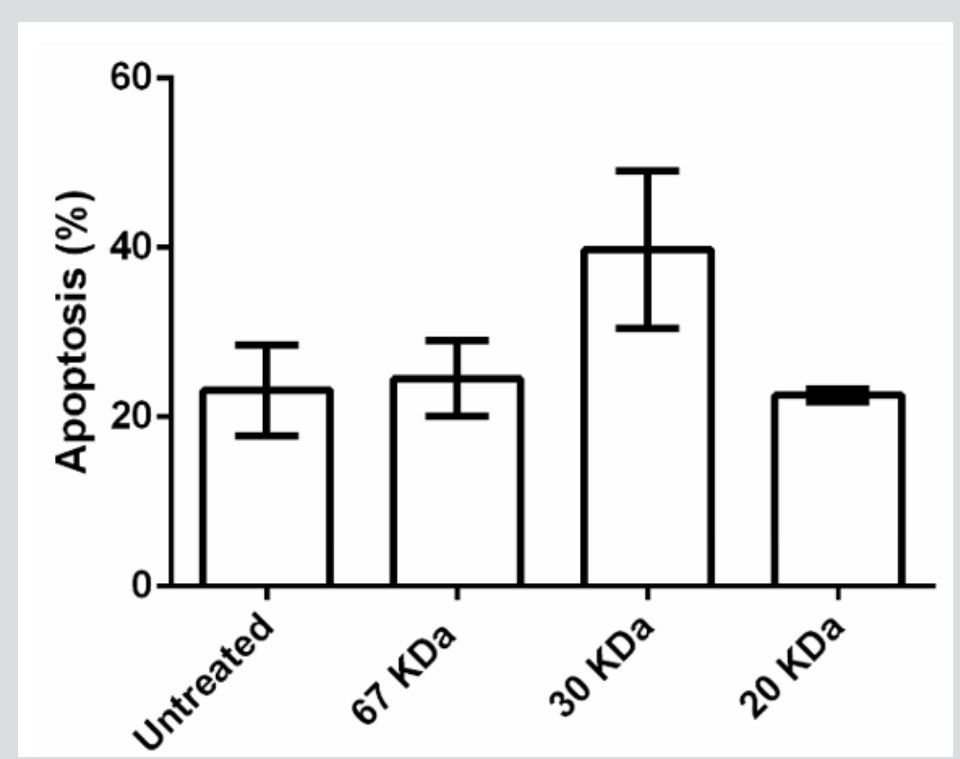

Figure 4: Effects of fractions on PBMC apoptosis. Based to results, just $30 \mathrm{KDa}$ fraction was induced apoptosis in PBMC normal cells.

\section{Discussion}

Since gastrointestinal cancer is seriously affecting a large number of people annually, introducing consumable plant sources and advocating a novel anti-cancer treatment might be helpful. In spite of an up-to-date improvement in control of carcinogens agents, the growing frequency and comparatively poor efficacy of chemotherapy have pushed the researchers for development of unique and promising methods. The majority of chemically cytotoxic medications which are commonly applied for cancer treatment have considerable adverse effects. So, it is ideal to look for development of innovative formulations from natural plant sources with significance functionality and minimal side effects 
[15]. Licorice is a well-known herbal medicine with considerable anti-inflammatory, anti-microbial, anti-fungal, antiviral and anticancer activities [16].

A number of herbal medicinal compounds have been assessed as anti-cancer agents versus HCT 116, esophageal and AGS cancer cells. Alsheri et al. [17] shown that Cichorium endivia L. phenolic extracts which involve a mixture of phenolic compounds have antiproliferative property on HCT-116 cancer cells. Bandopadhyaya et al. [18] have demonstrated that methanolic extracts of C. camphora, C. roseus and E. officinalison shows anti-proliferative activity on human colorectal cancer cells (HCT116) [18]. Sheng Li et al. [19] also showed that Crocetin applies a significant chemo-preventive upshot towards esophageal cancer via stopping cell proliferation, dissemination, and initiation of apoptosis [19]. In another study, Faried et al. [20] confirmed that the Gallic acid obtained from Indonesian medicinal plant, Phaleria macrocarpa, has antitumor outcomes on TE-2 as human esophageal cancer cells [20]. Heidari et al. [21] have reported Ferulago angulata Boiss extract has the anti-proliferative role and induces apoptosis on gastric cancer cell line (AGS) [21]. Kim et al. [22] also shown that ethanol extract of Rhus verniciflua Stokes brought on a dose-dependent reduction in the cell viability (IC50: $50 \mu \mathrm{g} / \mathrm{mL}$ ) and activated apoptosis through the intrinsic apoptosis pathway in human gastric cancer cells [22].

In another research, a couple of ingredients isolated from licorice named glycyrrhetinic acid and glycyrrhizic acid could increase death of cancer cells, following 24 and 48 hours of incubation and initiate apoptosis and cell cycle arrest in G1 phase. This might be because of an elevation in the PARP (Poly ADPribose polymerase) and caspase- 3 expression and the reduction of Bcl-xl, BCL2, cyclin D1 and cyclin E expression [23]. KhazraeiMoradian et al. [10] also showed that the licorice protein fractions brought the growth inhibition effect and induction of apoptosis in gastrointestinal cancer cell lines such as CT 26 and HT 29 [10]. Various non-protein licorice compounds most certainly revealed to acquire a good number of valuable activities which can include antioxidant [24], and antitumor [25] capabilities. The final result of non-protein licorice constituents on combating cancer was already explored quite a lot [26] and well indicated that it could cut back tumor growth and increase the lifelong of cancer victim mice [27].

Quite a lot of researchers have proven that non-protein ingredients obtained from the licorice root such as flavonoid, and polysaccharides have the ability to induce apoptosis in cancer cells, consequently being able to reverse the growth of cancer cells [28]. Aside from that, a number of investigations revealed that licorice and its bioactive constituents restrain cancer cell growth through induction of apoptosis, cell cycle arrest, and autophagy [29,30]. In brief, in this research, we characterized three proteins from the licorice root. A couple of them namely; dirigent protein 21-like and beta amylase-like isoform X1 showed a significant anti-proliferative effect and could induce apoptosis on the aforementioned cancerous cells with non-significant side effects on the normal cells at lower concentrations (up to $2 \mu \mathrm{g} / \mathrm{ml}$ ). This result was in consistency with our previous findings [10].

\section{Conclusion}

Our findings revealed that some protein fractions of licorice root extract could block proliferation of gastrointestinal cancer cells and induce their apoptosis. Furthermore, the application of FPLC together with sequencing data from MALDI-TOF mass spectrometry (MS) may open a new horizon for production pf recombinant forms of the characterized proteins for future studies.

\section{Acknowledgement}

This study was financially supported by The International Campus of Tehran University of Medical Sciences (Grant \# 32518). We would like to convey our gratitude to Immunology, Asthma \& Allergy Research Institute personnel.

\section{References}

1. Mathers C, Fat DM, Boerma JT (2008) The global burden of disease: 2004 update. World Health Organization.

2. Siegel RL, Miller KD, A Jemal (2015) Cancer statistics, 2015. CA: a cancer journal for clinicians 65(1): 5-29.

3. Asl MN, Hosseinzadeh H (2008) Review of pharmacological effects of Glycyrrhiza $s p$. and its bioactive compounds. Phytotherapy research 22(6): 709-724.

4. Richard RA, David B, Wood B (2001) Book Review.

5. Shibata S (1994) Anti-tumorigenic chalcones. Stem cells 12(1): 44-52.

6. Tsai JP, Lee CH, Ying TH, Lin CL, Lin CL, et al. (2015) Licochalcone A induces autophagy through PI3K/Akt/mTOR inactivation and autophagy suppression enhances Licochalcone A-induced apoptosis of human cervical cancer cells. Oncotarget 6(30): 28851-28866.

7. Agarwal R, Wang ZY, Mukhtar H (1991) Inhibition of mouse skin tumorinitiating activity of DMBA by chronic oral feeding of glycyrrhizin in drinking water. Nutr Cancer 15(3-4): 187-193.

8. Huang RY, Chu YL, Huang QC, Chen XM, Jiang ZB, et al. (2014) $18 \beta$-Glycyrrhetinic acid suppresses cell proliferation through inhibiting thromboxane synthase in non-small cell lung cancer. PloS one 9(4): e93690.

9. Wang ZY, Agarwal R, Khan WA, Mukhtar H (1992) Protection against benzo $[\alpha]$ pyrene-and $\mathrm{N}$-nitrosodiethylamine-induced lung and forestomach tumorigenesis in A/J mice by water extracts of green tea and licorice. Carcinogenesis 13(8): 1491-1494.

10. Khazraei Moradian S, Ganjalikhani Hakemi M, Andalib A, Yazdani R, Arasteh J, et al. (2017) The Effect of Licorice Protein Fractions on Proliferation and Apoptosis of Gastrointestinal Cancer Cell Lines. Nutrition and Cancer 69(2): 330-339.

11. Shi L, Tang C, Yin C (2012) Glycyrrhizin-modified O-carboxymethyl chitosan nanoparticles as drug vehicles targeting hepatocellular carcinoma. Biomaterials 33(30): 7594-7604.

12. Tang ZH, Li T, Tong YG, Chen XJ, Chen XP, et al. (2015) A systematic review of the anticancer properties of compounds isolated from licorice (Gancao). Planta medica 81(18): 1670-1687.

13. Hsu YL, Kuo PL, Lin CC (2005) Isoliquiritigenin induces apoptosis and cell cycle arrest through p53-dependent pathway in Hep G2 cells. Life sciences 77(3): 279-292.

14. Bode AM, Dong Z (2015) Chemopreventive effects of licorice and its components. Current Pharmacology Reports 1(1): 60-71.

15. Powis G (1983) Dose-dependent metabolism, therapeutic effect, and toxicity of anticancer drugs in man. Drug metabolism reviews 14(6): 145-1163. 
16. Kim JS, Park MR, Lee SY, Kim DK, Moon SM, et al. (2014) Licochalcone A induces apoptosis in KB human oral cancer cells via a caspasedependent FasL signaling pathway. Oncology reports 31(2): 755-762.

17. Alshehri A (2012) Molecular and biochemical evaluation of antiproliferative effect of (Cichorium endivia L.) phenolic extracts on cancer cell line HCT-116. Academic J Cancer Res 5(2): 53-60.

18. Bandopadhyaya S, Ramakrishnan M, Thylur RP, Shivanna Y (2015) Invitro evaluation of plant extracts against colorectal cancer using HCT 116 cell line. Int J Plant Sci Ecol 1(3): 107-112.

19. Li S, JIANG S, JIANG W, ZHOU Y, SHEN XY, et al. (2015) Anticancer effects of crocetin in human esophageal squamous cell carcinoma KYSE-150 cells. Oncology letters 9(3): 1254-1260.

20. Faried A, Kurnia D, Faried LS, Usman N, Miyazaki T, et al. (2007) Anticancer effects of gallic acid isolated from Indonesian herbal medicine, Phaleria macrocarpa (Scheff.) Boerl, on human cancer cell lines. International journal of oncology 30(3): 605-613.

21. Heidari S, Akrami H, Gharaei R, Jalili A, Mahdiuni H, et al. (2014) Antitumor activity of Ferulago angulata Boiss. extract in gastric cancer cell line via induction of apoptosis. Iranian journal of pharmaceutical research: IJPR 13(4): 1335-1345.

22. Kim JH, Kim HP, Jung CH, Hong MH, Hong MC, et al. (2006) Inhibition of cell cycle progression via p27Kip1 upregulation and apoptosis induction by an ethanol extract of Rhus verniciflua Stokes in AGS gastric cancer cells. International journal of molecular medicine 18(1): 201-208.

23. Mehdinejadiani M, Shirzad H, Fakhari SH, Jalali A (2015) An Evaluation the Effect of Glycyrrhetinic and Glycyrrhizic Acids Derived from Licorice Extract on Gastric Cancer Cell Lines. J Babol Univ Med Sci 17(9): 52-58.

\section{ISSN: 2574-1241}

DOI: 10.26717/BJSTR.2019.17.002964

Gholam Ali Kardar. Biomed J Sci \& Tech Res

(c) This work is licensed under Creative

Submission Link: https://biomedres.us/submit-manuscript.php
24. Engelhart MJ, Geerlings MI, Ruitenberg A, van Swieten JC, Hofman A, et al. (2002) Dietary intake of antioxidants and risk of Alzheimer disease. Jama 287(24): 3223-3229.

25. Ramos S (2007) Effects of dietary flavonoids on apoptotic pathways related to cancer chemoprevention. The Journal of nutritional biochemistry 18(7): 427-442.

26. Hu YW, Liu CY, Du CM, Zhang J, Wu WQ et al. (2009) Induction of apoptosis in human hepatocarcinoma SMMC-7721 cells in vitro by flavonoids from Astragalus complanatus. Journal of ethnopharmacology 123(2): 293-301.

27. Lee CK, Park KK, Lim SS, Park JH, Chung WY (2007) Effects of the licorice extract against tumor growth and cisplatin-induced toxicity in a mouse xenograft model of colon cancer. Biological and Pharmaceutical Bulletin 30(11): 2191-2195.

28. Rossi T, Benassi L, Magnoni C, Ruberto AI, Coppi A, et al. (2005) Effects of glycyrrhizin on UVB-irradiated melanoma cells. In vivo 19(1): 319-322.

29. Seon MR, Park SY, Kwon SJ, Lim SS, Choi HJ, et al. (2011) Hexane/ethanol extract of Glycyrrhiza uralensis and its active compound isoangustone A induce G1 cycle arrest in DU145 human prostate and 4T1 murine mammary cancer cells. The Journal of nutritional biochemistry 23(1): 85-92.

30. Yo YT, Shieh GS, Hsu KF, Wu CL, Shiau AL (2009) Licorice and licochalcone-A induce autophagy in LNCaP prostate cancer cells by suppression of Bcl-2 expression and the mTOR pathway. Journal of agricultural and food chemistry 57(18): 8266-8273.

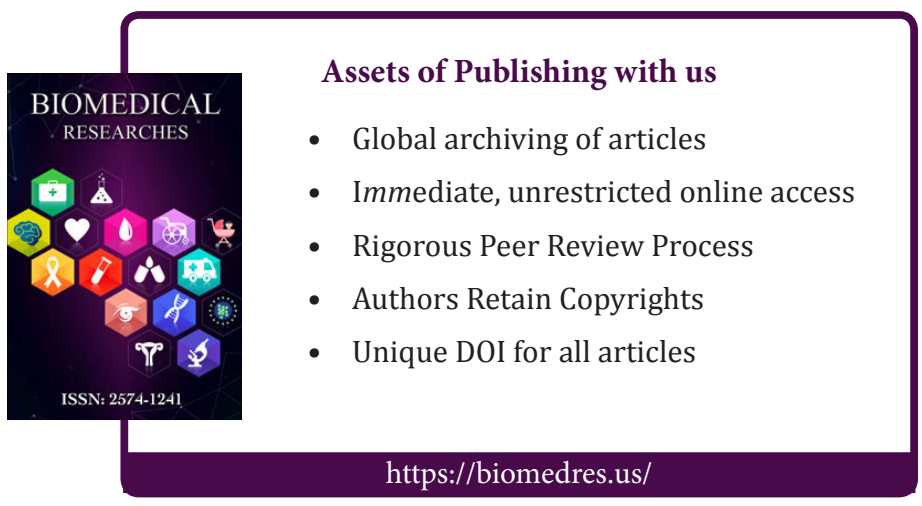

